\title{
Transformative Learning in the Art Museum: A Methods Review
}

Margaret S. Chisolm, MD; Margot Kelly-Hedrick, MBE; Mark B. Stephens, MD; Flora Smyth Zahra, DRestDent, RCS, MAClinEd

\begin{abstract}
Clinical educators are continually seeking innovative methods and settings for teaching. As such, they have increasingly begun to use art museums as a new educational space in which to build clinically-relevant skills and promote learners' professional identity formation. Art museum-based pedagogy can be understood through the framework of transformative learning theory, which provides an account of how adults learn through experience. In this article, the authors apply this theory to art museum-based teaching and offer a practical overview of art museum-based activities, highlighting three exemplars: visual thinking strategies, personal responses tour, and group poems. This toolbox of art museum-based teaching methods provides a launching pad for educators and learners to explore this innovative educational strategy.
\end{abstract}

(Fam Med. 2020;52(10):736-40.)

doi: 10.22454/FamMed.2020.622085

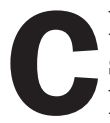
linical educators must ensure that health professions learners develop the knowledge, skills, behaviors, and attitudes to practice independently amidst the numerous, unpredictable challenges of the health care environment. A growing body of evidence suggests that an equally important educational responsibility is the support of professional identity formation (PIF),$^{1-3}$ allowing learners to "think, act, and feel" like competent health care professionals. ${ }^{4}$ Integrating the arts and humanities into health professions education (HPE) may enhance positive PIF among health professions learners and practitioners ${ }^{5}$ while improving clinical skills $^{6-9}$ and increasing joy and renewal. ${ }^{10,11}$ Accordingly the Association of American Medical Colleges has established a multiphase initiative, The Role of Arts \& Humanities in Physician Development: From
Fun to Fundamental. ${ }^{12}$ Most HPE research on the use of arts and humanities to support PIF examines methods implemented in classroom and clinical settings. Art museums are an innovative HPE space that may be particularly well-suited for promoting PIF by virtue of providing opportunities for fresh perspectives and new insights.

Art museum-based education represents a model case for transformative learning. The museum represents a new and creative environment for HPE that is physically distinct from usual teaching settings, offering a potentially stimulating space for students to learn. For some learners, the art museum is a place both unfamiliar, full of ancient art from different cultures, and familiar, sparking associations with one's own experiences. For these learners, the art and space itself may invoke welcome feelings of introspection, reflection, and connection with others across time, space, and culture. Other learners may experience the art museum entirely differently. For them, the museum may be boring, stodgy, or daunting (although the same might be said about medical school classrooms). It can elicit unexpected emotions and memories. It can surprise and provoke. It thus offers a unique setting for PIF and skills formations. ${ }^{5,7-9,13,14}$

Art museum-based education can enhance close observation/discrimination ${ }^{7,15,16}$ and communication/ collaboration skills integral to clinical practice. ${ }^{9}, 15,17,18$ These teaching methods can also promote critical thinking by enhancing students' and teachers' ability to observe, use evidence, speculate, and evaluate or revise ideas. ${ }^{19-21}$ More generally, artsbased teaching promotes a growth mindset by encouraging learners to embrace intellectual curiosity, perseverance, and tolerance of ambiguity. ${ }^{19,20}$ With skillful facilitation, these methods enable health care professionals to express their vulnerabilities and insecurities, and support

From the Department of Psychiatry and Behavioral Sciences (Dr Chisolm and Ms KellyHedrick), and Department of Medicine (Dr Chisolm), Johns Hopkins University School of Medicine, Baltimore, MD; Department of Family and Community Medicine, and Department of Humanities, Penn State College of Medicine (Dr Stephens); and Faculty of Dentistry, Oral and Craniofacial Sciences, King's College London (Dr Smyth Zahra). 
self-care. It is the combination of the museum space itself-often quiet, spacious, filled with natural light, and away from classrooms and clinical settings-and the art within the space that makes this learning environment special. While not everyone may have access to a local art museum and the associated educational resources due to geographic or other reasons (eg, a pandemic like COVID-19), art museum-based methods can be delivered in settings outside the museum, including online. Online art museum-based teaching allows access to nearly unlimited virtual collections of images and enables learners to reflect and engage from a location of their choosing.

Because art museum-based education is an emerging field with a relatively sparse literature, many health professions educators may be unfamiliar with its theoretical underpinnings and methods. This article provides a roadmap for using the art museum to promote transformational learning in the health professions.

\section{Pedagogical Foundation: Transformative Learning Theory (TLT)}

Although a growing body of evidence supports the use of art museum-based teaching, further research and critical analyses are needed to better understand its theoretical underpinnings and most effective application in HPE. Educational pioneer John Dewey warned that, without appropriate reflection on core educational values, systems are vulnerable to teaching fads..$^{22}$ It is important to consider each pedagogical practice in the context of a grounding educational theory to understand the effects that novel methods may have on outcomes relating to learner cognition and professional development.

As initially posited by Jack Mezirow, TLT describes how adults use their experiences to construct meaning and make sense of the world, and thus more easily handle similar situations in the future. ${ }^{23}$ Learners may sometimes encounter a situation so unfamiliar and challenging that it alters their existing understanding of the world. ${ }^{23}$ Mezirow refers to these situations as "disorienting dilemmas" and suggests they are necessary, but not sufficient to prompt true learning ${ }^{23}$ and transformation. ${ }^{24}$ In order for these to occur, learners must also engage in critical reflection of their own underlying cognitive and affective perspectives, a process that occurs most effectively when learners can discuss ideas with one other. ${ }^{25-27}$

Tebogo Tsimane and Charlene Downing operationalize Mezirow's model into three elements: (1) antecedents, (2) processes and procedure, and (3) outcomes. ${ }^{28}$ Antecedents refer to preexisting cognitive and affective perspectives. The transformative learning process can be triggered by an uncomfortable situation that, coupled with reflection and discussion, prompts learners to question these perspectives. The resulting change in perspective is classified as an outcome of the transformation.

\section{Art Museum-Based Education and Transformative Learning}

For health professions learners who are more familiar with classrooms and clinics than art museums, art and the museum itself provide disorienting dilemmas that may trigger transformation. The interactive and group-based activities, and the interactive nature of art museum-based teaching further promote the critical reflection and discourse necessary for growth. Through individual and group exercises designed to promote reflection, learners can begin to question some of their previously established cognitive and affective perspectives. They can be inspired to create and test alternative world views, a phenomenon that can lead to transformation.

When developing growth-promoting experiences, educators should consider multiple curricular goals. They must assess the needs of each learner and encourage learners to define and evaluate specific learning goals. Experiences should promote a collaborative problem-solving approach within a supportive learning environment. Teaching methods should also foster experiential and participatory engagement of learners. ${ }^{29}$

In contrast to the traditional delivery of learning objectives at the beginning of educational activities, art museum-based teaching typically involves minimal up-front instruction. This is intentional to create the disorienting dilemma necessary for transformative learning. Encouraging learners to embrace the unfamiliar and address ambiguity can enhance their ability to grow and change.

Most art museum-based activities involve small groups of learners, ideally led by a health professions educator and museum educator dyad (Table 1). After each activity, one or both of these leaders guide learners through a debriefing to discuss their perceptions of the activity and share in a group reflective process. This post hoc analytic process promotes learner autonomy, reinforces key principles, and validates the importance of multiple perspectives when approaching ambiguous problems commonly seen in clinical care.

Mezirow suggests that transformation can occur after a single experience or through multiple experiences..$^{23}$ Educators designing and leading art museum-based longitudinal curricula need not feel pressured to ensure that every activity is emotionally charged and/or otherwise disorienting. With adequate time for iterative exposure, a curriculum can begin with simple experiences to develop learners' comfort with the art museum setting and then gradually incorporate more challenging or provoking scenarios.

\section{Toolbox of Art Museum- Based Activities}

The art museum offers many ways for health professions learners to engage in reflective, growth-promoting experiences (Table 1). Visual thinking strategies (VTS), the personal responses tour (PRT), and group poems are among the most widely used art 
Table 1: A Description of Select Art Museum-Based Methods

\begin{tabular}{|c|c|c|c|c|c|c|}
\hline Activity Name & $\begin{array}{c}\text { Clinically Relevant } \\
\text { Domains }\end{array}$ & $\begin{array}{l}\text { Minimum } \\
\text { Participant } \\
\text { Number }\end{array}$ & $\begin{array}{l}\text { Ideal Student- } \\
\text { Facilitator } \\
\text { Ratio }\end{array}$ & $\begin{array}{l}\text { Minimum } \\
\text { Allotted } \\
\text { Time }\end{array}$ & $\begin{array}{c}\text { Advance } \\
\text { Preparation }\end{array}$ & Supplies \\
\hline $\begin{array}{l}\text { Visual thinking } \\
\text { strategies }\end{array}$ & $\begin{array}{l}\text { Observation skills } \\
\text { Reasoning skills } \\
\text { Critical thinking }\end{array}$ & 4 & $15: 1$ & 15 min. & $\begin{array}{l}\text { Carefully select a } \\
\text { piece of art } \\
\text { Facilitator should } \\
\text { be trained in } \\
\text { VTS }^{1}\end{array}$ & None \\
\hline $\begin{array}{l}\text { Personal } \\
\text { responses tour }\end{array}$ & $\begin{array}{l}\text { Self- and team-reflection } \\
\text { Self-care } \\
\text { Observation skills } \\
\text { Professional identity } \\
\text { formation }\end{array}$ & 4 & $15: 1$ & $\begin{array}{l}1.5 \text { hours } \\
\text { per } 15 \\
\text { students }\end{array}$ & $\begin{array}{l}\text { Create tags with } \\
\text { prompts and } \\
\text { select galleries }\end{array}$ & $\begin{array}{l}\text { - Tags with } \\
\text { prompts } \\
\text { - Basket } \\
\text { or bag for } \\
\text { prompts }\end{array}$ \\
\hline Group poems & $\begin{array}{l}\text { Team building } \\
\text { Dealing with uncertainty } \\
\text { Observation skills }\end{array}$ & $\begin{array}{l}10 \\
\text { (two } \\
\text { groups of } \\
\text { five })\end{array}$ & $5: 1$ & 30 min. & $\begin{array}{l}\text { Select } 1 \text { piece of } \\
\text { art containing at } \\
\text { least } 1 \text { figure for } \\
\text { each group }\end{array}$ & $\begin{array}{l}\text { - Strips of } \\
\text { blank paper } \\
\text { - Piece of } \\
\text { construction } \\
\text { paper (1 per } \\
\text { group) } \\
\text { - Tape } \\
\text { - Pencils } \\
\end{array}$ \\
\hline $\begin{array}{l}\text { Seeing and } \\
\text { thinking }\end{array}$ & $\begin{array}{l}\text { Observation skills } \\
\text { Critical thinking } \\
\text { Dealing with ambiguity }\end{array}$ & 4 & $10: 1$ & 30 min. & None & $\begin{array}{l}\text { - Paper } \\
\text { - Pencils } \\
\text { - Clipboards }\end{array}$ \\
\hline And I noticed & $\begin{array}{l}\text { Observation skills } \\
\text { Dealing with uncertainty } \\
\text { Wellness/self-care } \\
\text { Identity formation } \\
\text { Interpersonal } \\
\text { communication }\end{array}$ & 4 & $10: 1$ & 30 min. & None & $\begin{array}{l}\text { - Paper } \\
\text { - Pencils } \\
\text { - Clipboards }\end{array}$ \\
\hline Back to back & $\begin{array}{l}\text { Observation skills } \\
\text { Interpersonal } \\
\text { communication } \\
\text { Dealing with uncertainty }\end{array}$ & 6 & $12: 1$ & $30 \mathrm{~min}$. & None & $\begin{array}{l}\text { - Paper } \\
\text { - Pencils } \\
\text { - Clipboards }\end{array}$ \\
\hline $\begin{array}{l}\text { The labyrinth. "I } \\
\text { used to think, ... } \\
\text { Now I think" }\end{array}$ & $\begin{array}{l}\text { Wellness/self-care } \\
\text { Reflection and self- } \\
\text { regulation } \\
\text { Dealing with uncertainty } \\
\text { Identity formation }\end{array}$ & 4 & $10: 1$ & $\begin{array}{l}1 \text { hour, } 15 \\
\text { min. }\end{array}$ & None & None \\
\hline $\begin{array}{l}\text { Look at me } \\
\ldots \text { am I an } \\
\text { Imposter? }\end{array}$ & $\begin{array}{l}\text { Identity formation } \\
\text { Wellness/self-care } \\
\text { Reflection and self- } \\
\text { regulation } \\
\text { Dealing with uncertainty }\end{array}$ & 4 & $10: 1$ & $45 \mathrm{~min}$. & None & $\begin{array}{l}\text { - Paper } \\
\text { - Pencils } \\
\text { - Clipboards }\end{array}$ \\
\hline Mask making & $\begin{array}{l}\text { Observation } \\
\text { Self-regulation } \\
\text { Identity formation }\end{array}$ & 1 & $10: 1$ & $60 \mathrm{~min}$. & None & $\begin{array}{l}\text { - Blank } \\
\text { masks }^{3} \\
\text { - Craft } \\
\text { supplies (eg, } \\
\text { papier-mâché, } \\
\text { acrylic paint, } \\
\text { ribbon, paper, } \\
\text { markers, } \\
\text { feathers, glue, } \\
\text { scissors) }\end{array}$ \\
\hline
\end{tabular}

${ }^{1}$ VTS trainings: https://vtshome.org/events/

${ }^{2}$ Museums do not allow pens or markers in the galleries (pencils are usually acceptable).

${ }^{3}$ For a more extensive supply list and prompts, contact mstephens3@pennstatehealth.psu.edu. 
museum-based teaching tools and exemplify how art museum-based methods can be used in HPE.

\section{Visual Thinking Strategies}

VTS is an approach that facilitates open-ended group discussions about art. VTS is the most widely used and studied art museum-based pedagogical method in HPE. In VTS, participants view and discuss works of art together, prompted by questions that support responses grounded in close looking and that hold the group in shared inquiry. Although all art is ambiguous at some level (because the viewer can never be exactly certain as to what the artist intended), the art selected for VTS needs to contain enough ambiguity to promote differing interpretations during the discussion, thereby creating a slightly disorienting dilemma. The facilitator leads the group using the three basic questions "What's going on in this picture?" "What do you see that makes you say that?" and "What more can we find?" 30 Additionally, the facilitator points to what is being described and paraphrases and links learners' responses. Although VTS may sound simple, expert VTS facilitation often requires years of specialty training and practice.

VTS was originally designed to promote the aesthetic development (ie, understanding when looking at art) of K-12 learners, but teachers began to notice their learners applied the critical thinking strategies learned in VTS to other, nonart subjects. $^{30}$ This prompted VTS developers Abigail Housen and Philip Yenawine to conduct a longitudinal controlled trial of VTS' effect on critical thinking and its transfer among early learners; results suggested that VTS improves critical thinking skills that transfer to different subject domains $^{30}$

VTS has been used and studied with a variety of health professions learners, including undergraduate and graduate medical trainees, as well as nursing learners. ${ }^{31}$, ${ }^{32}$ Most of the published studies on VTS in health professions learners are single-site descriptions of cross-sectional outcomes based on learner self-reports and lack a comparison group, limiting the conclusions that can be drawn from the evidence. ${ }^{9,13,15,33}$

\section{Personal Responses Tour}

In a PRT, participants individually explore a set of galleries in the art museum in search of a work of art that responds to a unique prompt. After independently reflecting on the connection between the art and the prompt, participants then reconvene to tour the galleries together, sharing their selections, prompts, and reflections with one other. ${ }^{34,35}$ Prompts can be drawn from the literature ${ }^{34,}$ ${ }^{35}$ or facilitators can create unique prompts to match specific learners and/or curricular needs. PRT invites learners to personally reflect on the relationship between a work of art and a prompt—an atypical cognitive task in HPE.

PRT has not been evaluated as extensively as VTS. One small study of medical students and residents suggests that PRT promotes community building, empathic listening, and appreciation of multiple perspectives. PRT also offers a reprieve from busy clinical work, promoting renewal and personal reflection. ${ }^{34}$ However, much more work needs to be done to assess the impact of PRT on learner outcomes, before drawing any definitive conclusions about its utility in HPE.

\section{Group Poems}

In contrast to the previous two examples, the group poem activity involves an act of art creation. In this activity, teams are divided into small groups to work together to create a written work based on a shared visual and spoken prompt. Each small group is assigned to review a different preselected work of art that depicts at least one figure. After examining the assigned artwork, participants are asked to write down a phrase that they imagine a figure in the artwork might be saying. Each participant reads their phrase aloud to the group. Together, the group then sequences all of the phrases into a collective poem, which is then shared with the other group(s). Participants often realize both the differences in perspectives represented by the variation in phrases within the group and that there is no right way to assemble the poem. For some, understanding how their peers interpret a work of art differently can transform how they view the art, creating the type of unusual experience that may spark growth. To the authors' knowledge, an evaluation of this art museum-based activity has not been reported in the literature. However, this teaching tool could potentially enhance several clinically relevant skills, including close observation, communication, empathy, and teamwork.

\section{Discussion}

Health professions educators are discovering how the art museum can be a setting for learners to build clinical skills and engage in critical reflection and discussion on matters relevant to life in medicine. Art museum-based teaching methods can be developed and adjusted for learners at any level of training. A major potential benefit of art museum-based HPE is that the museum can provide the time and space away from clinical demands that many learners need to engage in reflection and meaningful dialogue. The museum and its art can support many learners who seek to reconnect with themselves and their core values. As the concept of transformation and its core components are defined in ways that are more concrete and measurable, the ability for HPE researchers to examine the mechanisms by which art museum-based teaching may support transformative learning will expand, as will the opportunity to more rigorously evaluate any impact of this pedagogy on learners.

\section{Conclusion}

Art museum-based education is an emerging field with a relatively sparse literature, thus many health 
professions educators may be unfamiliar with its theoretical underpinnings and methods. In this article, we described TLT and suggested a rationale for grounding art museumbased pedagogical methods in this theoretical foundation. We provided a road map and toolbox of activities to guide and support educators in the use of art museums for transformative learning. We presented these resources in the context of the growing body of literature and increasing institutional attention on the role of the arts and humanities in HPE, that we hope will pique interest in this exciting field and encourage health professions educators to try some of these teaching methods.

ACKNOWLEDGMENTS: The authors acknowledge the Cambridge Health Alliance Center for Professional and Academic Development and the Harvard Macy Institute's Art MuseumBased Health Professions Educators Fellowship and its faculty team including museum educators Corinne Zimmermann and Ray Williams and medical educators Liz Gaufberg and Lisa Wong. The authors also thank Elizabeth Ryznar, Scott Wright, and Philip Yenawine for their comments and suggestions on earlier drafts of the manuscript.

FINANCIAL SUPPORT: Dr Chisolm is the Director of the Paul McHugh Program for Human Flourishing, through which her work is supported.

CORRESPONDING AUTHOR: Address correspondence to Dr Margaret Chisolm, Department of Psychiatry and Behavioral Sciences, and of Medicine, Johns Hopkins University School of Medicine, 5300 Alpha Commons Drive, Baltimore, MD 21224. 410-550-9744. mchisol1@jhmi.edu.

\section{References}

1. Cooke M, Irby DM, O'Brien BC. Educating Physicians: A call for reform of medical school and residency. San Francisco: Jossey-Bass; 2010.

2. Cruess RL, Cruess SR, Boudreau JD, Snell L, Steinert Y. A schematic representation of the professional identity formation and socialization of medical students and residents: a guide for medical educators. Acad Med. 2015;90(6):718-725.
3. Sharpless J, Baldwin N, Cook R, et al. The becoming: students' reflections on the process of professional identity formation in medical education. Acad Med. 2015;90(6):713-717.

4. Merton RK, Reader G, Kendall PL, eds. The student physician: Introductory studies in the sociology of medical education. Harvard University Press; 1957.

5. Lazarus PA, Rosslyn FM. The Arts in Medicine: setting up and evaluating a new special study module at Leicester Warwick Medical School. Med Educ. 2003;37(6):553-559.

6. Gurwin J, Revere KE, Niepold S, et al. A randomized controlled study of art observation training to improve medical student ophthalmology skills. Ophthalmology. 2018;125(1):8-14.

7. Naghshineh S, Hafler JP, Miller AR, et al. Formal art observation training improves medical students' visual diagnostic skills. J Gen Intern Med. 2008;23(7):991-997.

8. Dolev JC, Friedlaender LK, Braverman IM Use of fine art to enhance visual diagnostic skills. JAMA. 2001;286(9):1020-1021.

9. Schaff PB, Isken S, Tager RM. From contem porary art to core clinical skills: observation, interpretation, and meaning-making in a complex environment. Acad Med. 2011;86(10):12721276.

10. Gordon J. Medical humanities: to cure sometimes, to relieve often, to comfort always. Med J Aust. 2005;182(1):5-8.

11. Stuart E. Art and grieving: a reflection on justin-time education. J Palliat Med. 2003;6(2):270 275.

12. Association of American Medical Colleges. The role of arts and humanities in physician development: from fun to fundamental. https://www. aamc.org/initiatives/meded/494588/roleofartsandhumanitiesinphysiciandevelopment.html. Accessed September 9, 2019.

13. Bentwich ME, Gilbey P. More than visual literacy: art and the enhancement of tolerance for ambiguity and empathy. BMC Med Ed. 2017;17(1):200

14. Shapiro J, Coulehan J, Wear D, Montello M. Medical humanities and their discontents: definitions, critiques, and implications. Acad Med. 2009;84(2):192-198.

15. Bardes CL, Gillers D, Herman AE. Learning to look: developing clinical observational skills at an art museum. Med Educ. 2001;35(12):11571161

16. Katz JT, Khoshbin S. Can visual arts training improve physician performance? Trans Am Clin Climatol Assoc. 2014;125:331-341.

17. Kumagai AK. Perspective: acts of interpretation: a philosophical approach to using creative arts in medical education. Acad Med. 2012;87(8):1138-1144.
18. Reilly JM, Ring J, Duke L. Visual thinking strategies: a new role for art in medical education. Fam Med. 2005;37(4):250-252.

19. He B, Prasad S, Higashi RT, Goff HW. The art of observation: a qualitative analysis of medical students' experiences. BMC Med Educ. 2019;19(1):234.

20. Haidet P, Jarecke J, Adams NE, et al. A guiding framework to maximise the power of the arts in medical education: a systematic review and metasynthesis. Med Educ. 2016;50(3):320-331.

21. Perry M, Maffulli N, Willson S, Morrissey D. The effectiveness of arts-based interventions in medical education: a literature review. Med Educ. 2011;45(2):141-148.

22. Dewey J. Democracy and Education: An Introduction to the Philosophy of Education. New York, NY: Cosmo Classics; 1916.

23. Mezirow J. Transformation theory of adult learning. In: Welton MR, ed. In Defense of the Lifeworld. New York: SUNY Press; 1995:39-70.

24. Mezirow J. Understanding transformation theory. Adult Educ Q. 1994;44(4):222-232.

25. Cranton P. Understanding and Promoting Transformative Learning: A Guide for Educators of Adults. San Fransisco: Jossey-Bass; 1994.

26. Mezirow J. Transformative learning: theory to practice. New Dir Adult Contin Educ. 1997;74(74):5-12.

27. Mezirow J. On critical reflection. Adult Educ Q. 1998;48(3):185-198

28. Tsimane TA, Downing C. Transformative learning in nursing education: a concept analysis. Int J Nurs Sci. 2019;7(1):91-98.

29. Mezirow J. Transformative dimensions of adult learning. San Francisco: Jossey-Bass; 1991.

30. Housen AC. Aesthetic thought, critical thinking and transfer. Arts and Learning Research. 2002;18(1):2001-2002.

31. Klugman CM, Peel J, Beckmann-Mendez D. Art Rounds: teaching interprofessional students visual thinking strategies at one school. Acad Med. 2011;86(10):1266-1271.

32. Moorman M, Hensel D, Decker KA, Busby $\mathrm{K}$. Learning outcomes with visual thinking strategies in nursing education. Nurse Educ Today. 2017;51:127-129.

33. Frei J, Alvarez SE, Alexander MB. Ways of seeing: using the visual arts in nursing education. J Nurs Educ. 2010;49(12):672-676.

34. Gaufberg E, Williams R. Reflection in a museum setting: the personal responses tour. $\mathrm{J}$ Grad Med Educ. 2011;3(4):546-549.

35 . Williams R. Honoring the personal response. J Mus Educ. 2010;35(1):93-102. 